\title{
Modeling of Different Levels Territories Sustainable Development
}

\author{
E.G. Efimova ${ }^{1, *}$, T.R. Lukashenok ${ }^{1}$, O.K. Khorzhan ${ }^{2}$ \\ ${ }^{1}$ Ural State University of Economics, Yekaterinburg, Russia \\ ${ }^{2}$ State Agrarian University of Moldova, Chisinau, Moldova \\ *Corresponding author.Email: levstrelkov@mail.ru
}

\begin{abstract}
The study made it possible to determine the impact of the legislative level on the sustainable development of territories and the choice of tools for solving urgent strategic tasks. Based on the analysis, generalization and systematization of various materials in the field of sustainable development, national interests and strategic priorities of sustainable development are identified in the context of territorial levels. The relevance and globality of sustainable development topic refers it to the sphere of state interests and scientific research. The scientific and technological progress necessary for society generates a global environmental catastrophe, but it is impossible to increase the effectiveness of social formation development in the future without it. This confrontation necessitated the identification of problem fields and the search for ways to solve urgent strategic tasks in the field of territories of different levels sustainable development within national borders.
\end{abstract}

Keywords: sustainable development, national priorities, strategic interests, national security, model of territories sustainable development.

\section{INTRODUCTION}

In the scientific discourse, the topic of territories at various levels sustainable development (from global to local) seems relevant. This new scientific direction has been emerging since the 1960s of the XX century, when ideas about the need to find new ways of developing the world community appeared, and in the period from 197080 [1], when global development problems were recognized, expressed in the limited resources of the planet for the growing needs of mankind, sustainable development takes the form of an current agenda for the world community.

The works of scientists in the field of sustainable development reveal that it is scientific and technological progress that determines social evolution that is the main cause of the global environmental catastrophe. This fact is substantiated in the report of the World Commission on Environment and Development in 1987 [2], in which the term "sustainable development" was first described.

In 1992, following the results of the UN Conference on Environment and Development, the Concept of Sustainable Development was adopted [3], which contains specific recommendations to governments on the development of national strategies in this area. In the same year, the Concept of Sustainable Economic Growth and Development was put into effect in Russia, in addition to the National Action Plan for Environmental Protection.

In 1994, the Decree of the of the Russian Federation President approved the State Strategy of the Russian Federation for Environmental Protection and Sustainable Development [4] and two years later, the fundamental normative document in the field of sustainable development, Decree of the of the Russian Federation President No. 440 of April 1, 1996 on the approval of the Concept of the transition of the Russian Federation to sustainable development was approved as well [5] with a system of perspective provisions for the country on the threshold of the XXI century.

In 1995, the UN Special Commission on Sustainable Development worked out a project program containing a system of sustainable development indicators (contains 132 indicators), distributed into 4 groups: 1) indicators of social aspects; 2) indicators of economic aspects; 3 ) indicators of environmental aspects; 4) indicators of institutional aspects [6]. These groups of indicators are 
recommended by the UN for the use in strategic and program documents of national economies $[7,8,9]$.

The concept of sustainable development does not lose its relevance and significance for any country in the world $[10,11,12]$, in connection with which its provisions have a legislative and legal basis and should be able to improve it in the future due to constantly occurring socio-economic changes.

The purpose of this work is to determine the links in the sphere of the legislative level influence on sustainable development in the territorial context, and tools for solving current strategic tasks of the territories.

\section{MATERIALS AND METHODS}

The authors carried out a review, generalization and systematization of scientific works in the field of sustainable development provisions, strategic interests and priorities of national security, economic security of territories contained in state legislative documents. The concept of sustainable development concerns both Russian and foreign authors, is an important issue of state interests, its provisions are enshrined in regulatory documents, have a vivid legal and political character, which affects the foreign policy countries relations in various areas of national interests (opportunities for the development of societies, economy, environmental protection, etc.).

The existence of growth limits for each national economy is indicated in the researches of foreign scientists [13, 14]. The threats faced by the world community as a result of the negative human impact on the environment are highlighted in the following works. For example, there is the famous book by R. Carson "Silent Spring", studies by J. Galbraith, A. Aron, A. Pechchei and many others, and among Russian scientists one can cite scientific works by A.G. Granberg, V.I. Vernadsky and many others investigating the mechanisms of environmental destruction [6].

In the evolution of the concept, scientists distinguish the stages of development. For example, in the works by Belousov K.Yu. [15], Pashkevich M.S. and Shapoval V.M. [16], three stages with common features are identified: the initial stage, the stage of formation and development, the stage of highlighting problems and developing directions in the field of sustainable development. Four stages were identified in the scientific studies by Krasnoshchekov G.P. and Rosenberg G.S. [17], where the division was based on any significant processes occurring in the evolution of the concept. Pasenov A.N. [1] identifies two stages as he believes that, in general, the first stage involved the development of the fundamental elements of the concept, and the second stage involves the normative consolidation and justification of the developed provisions of the concept, its improvement.
As for the term of "sustainable development", we can say that it became popular after the publication of the report "Our Common Future" in 1987, and its essence is revealed from the perspective of such a development level that allows not endangering future generations as a result of meeting the needs of the generation in the present [2].

The concept of "sustainable development" is generally understood as a state of "dynamic or stable equilibrium" of society, "which, in response to changes in internal and external conditions, is able to establish a new equilibrium corresponding to these changes both within itself and within its habitat" [18, p. 125]. Alferova T.V., Tretyakova E.A. understand the essence of the concept as a set of certain processes that promote harmonization between the economic, environmental and social spheres, which allows meeting the needs of the socio-economic system in the long term [19]. As Gizatullin H.N. and Troitsky V.A. write, "a universally recognized definition of sustainable development" has not yet been formulated [18, p. 129]

It is obvious that the sustainability of the country's territories development depends on the state of its internal environment (socio-economic) and the external political and economic situation. In this regard, strategic priorities in the field of sustainable development are dynamic, which must be taken into account in strategic planning, in state regulatory and legislative documents, programs, etc.

As a result of scientific research, it has been revealed that growth rates are not of decisive importance in the quantitative dimension of the economy (as an increase in the scale of the economy in the physical dimension), but, on the contrary, its qualitative improvements represent an important essence [18]. So, this provision determines that economic development can become sustainable if there is a qualitative meaning in it.

It is obvious that the sustainability of development is directly related to the level of the state of national security (one of the most important strategic tasks of the nation). The sphere of the economic component in the national security system of the country was studied in detail in one of the authors' works on assessing the economic security of territories at different levels [20], which made it possible to highlight the sphere of the most important strategic interests and priorities in the system of ensuring the national security of the Russian Federation at the present time. The interdependence between the state of the state security system, the well-being of people and the sustainable development of the country's territories is also obvious.

It is obvious that the sustainability of development is directly related to the level of national security (one of the most important strategic tasks of the nation). The sphere of the economic component in the national 
security system of the country was studied in detail in one of the authors' works on the assessment of the economic security of territories of different levels [20], which made it possible to identify the sphere of the most important strategic interests and priorities in the system of ensuring the national security of the Russian Federation at the present time. The interdependence between the state of the state security system, the well-being of people and the sustainable development of the country's territories is also obvious.

Sustainable development of territories at all levels should be investigated and evaluated in three planes: in the present, in the past and in the future. Sustainability factors of development of various territorial levels have both general and individual characteristics. It is important to take into account that at each territorial level its stability will depend on or have zones of intersection with other levels. The formation of sustainability begins with the local and municipal level of the territory - this is the basis, the foundation for building the sustainability of all higher levels (subject, macroregion, country) [21]. For example, the achieved level of sustainable development of a municipality means achieving a certain level of wellbeing of the population of a given territory and each individual in the municipality. The formation of the sustainability of the subject's development is based on the achieved level of well-being and sustainability of the development of all its constituent municipalities, to which it is necessary to add the definition of strategic development priorities at the regional level regarding the conditions and opportunities of the region as a whole. At the regional level, including at the macroregion level, the specialization of the territory, internal and external economic relations are being formed, regional policy and strategy are being developed, coordinated with state regulatory and legislative documents, allowing achieving sustainable socio-economic development at the national level. Thus, the sustainability of the development of the state as a whole has internal components in relation to its territorial hierarchy, which represent the basis, and external components, where the sustainability of development is determined by the country's ability to maintain the achieved level of sustainability in development and manage its changing state in the future.

Based on the materials studied, as a way to solve certain strategic planning tasks, we have developed an author's integral model of sustainable development that unites territories of any level.

\section{RESULTS AND DISCUSSION}

Research in the field of sustainable development and economic growth in Russia allows us to formulate some conclusions.

In general, two main stages can be distinguished in the formation of sustainable development concept, where at the first stage "the main provisions of the future concept were formed", a general understanding and understanding of its essence, criteria and indicators of sustainability were defined, normative consolidation of the theoretical and methodological provisions being developed, and at the second stage the main provisions of the concept were clarified and detailed [1, p. 160].

The concept of sustainable development seems to be a new qualitative approach to solving global problems, allowing to rethink the ecological and economic state of the planet, to look for ways of coexistence of mankind with the environment, where effective development strategies need to be developed [22].

Currently, the term "sustainable development" is fixed in the legal field of the Russian Federation only in relation to two areas: at the national level, it is ensuring a decent standard of living and preserving the traditions of indigenous small-numbered peoples living on the territory of the Russian Federation [23, 24], at the level of subjects, it is the development of infrastructure and the life quality of rural population $[25,26]$. This shows some legislative limitations, which necessitated further study and formation of the concept of "sustainable development" in legal interpretation, as well as the impact of the achieved level of development on the ongoing economic processes aimed at achieving the essence of the above-mentioned term.

The study allows us to offer an integral model of sustainable development in the context of national interests and strategic priorities, combining the territorial levels necessary for the functioning of the state, with the allocation of basic and variable blocks at the macroregional level, main and derived blocks at the level of subjects that are part of the state as territorial elements (Fig. 1).

The model is based on national interests and strategic priorities presented in the new National Security Strategy of the Russian Federation [27], taken as the main guidelines for sustainable development.

We offer to group national interests into functional blocks (interests of the state block, economy and ecology, human potential), which, in our opinion, will contribute to a more effective correlation of the directions of ensuring sustainable development of the second and third level territories (subjects and municipalities) with the interests of the state, society and the individual.

The "state block" is offered to include such national interests as ensuring the country's defense, achieving and maintaining national accord, and ensuring strategic stability. The block "economics and ecology" includes the economy development on the basis of a new technological order, ensuring information security, environmental protection. The "human potential" block implies national interests in improving the quality of life, as well as preserving traditional spiritual and moral 
values. Strategic national priorities are distributed among these blocks. The system of national interests and strategic priorities represent the highest national level of the territorial hierarchy of the Russian Federation.

To ensure the sustainable development of the territories that are lower in the hierarchy, we will decompose national interests and strategic national priorities to the level of macro-regions identified in the Spatial Development Strategy of the Russian Federation in 2019 [28].

At the level of macro-regions, the achievement of national interests and strategic priorities is ensured through the following development directions: interregional integration (allows ensuring the national interests of the state bloc); economic growth, infrastructure development, introduction of scientific and technological progress technologies (aimed at satisfying national interests in the field of economics and ecology); preservation of population and improvement of life quality (realize national interests in the field of human potential). Depending on the peculiarities of development, economic specialization, geography of the macroregion, the degree of priority of each of the above directions is determined, besides they are all basic, that is, mandatory. The variable blocks included in the model contain directions that are implemented additionally or are not implemented depending on the specifics, strategic and resource orientation of the region, or include directions that require special support conditions. These areas include the conditions for the development of rural areas, the maintenance of life support for indigenous small-numbered peoples living on the territory of the Russian Federation.

The directions offered at the macro-regional level can be decomposed into the level of subjects within the state. Based on the criteria: specialization of the region, the level of socio-economic development, economic and geographical location, specific features presented at the level of the macroregion, it is advisable to rank the directions by priority. At the same time, we offer to allocate the main and derived blocks in these directions, that is, the effective implementation of measures to meet the needs of the main blocks will contribute to the synergetic activation of the derived blocks. The selected

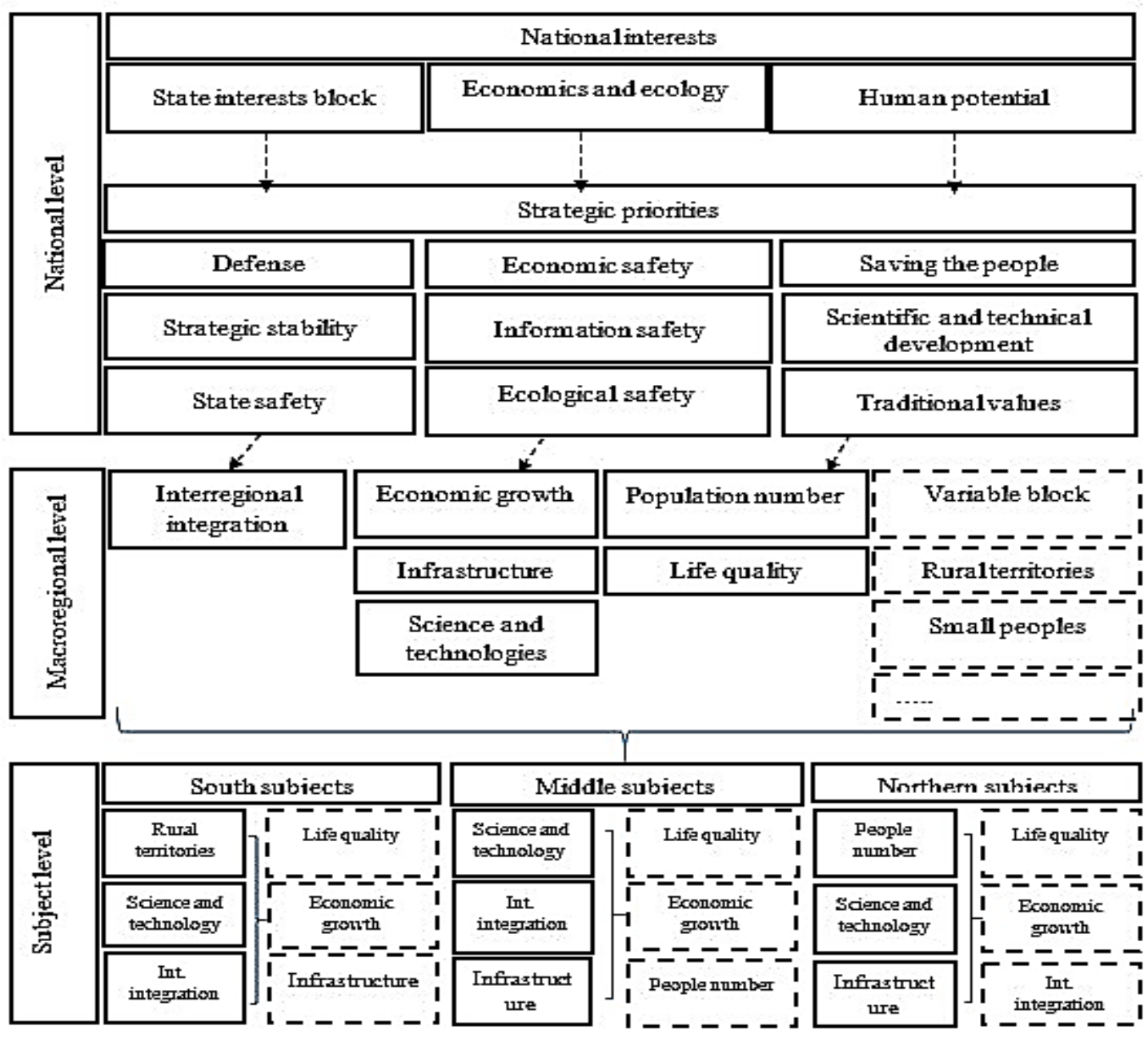

Figure 1 Integral model of territories sustainable development 
criteria, including geographical features of the region location, allowed us to assume the priority of directions and the composition of the main blocks for the territories located in the northern part of the country, in the south and in the middle zone, all of them have their own characteristics and unique characteristics that distinguish the territories from each other.

For example, the Sverdlovsk Region belongs to the middle territories of the country, where the main specialization is metallurgical production. From the socio-economic development level, this subject of the Russian Federation is characterized as self-sufficient. From the point of view of location and taking into account the main specialization, the logistics capabilities of the region are of great strategic importance. It is advisable to attribute the functioning of the Ural mining industry to specific features $[29,30]$. Based on the analysis of the above criteria, the main blocks should be identified as the development of science and technology, in particular engineering, ensuring interregional integration, taking into account the middle position of the region as its uniqueness (between Europe and Asia), and infrastructure development. By satisfying the needs of the main blocks, the subject will be able to ensure a decent quality of life for the population, economic growth trends, population balance (between cities and rural areas).

As an example of the southern territory, let's give the Republic of Bashkiria. The main specialization of this subject of the Russian Federation is the sphere of agriculture, from the socio-economic development point of view there is a risk of subsidization, geography is important in connection with the main specialization, the need to ensure the safety of agricultural land should be attributed to the specifics. Given these circumstances, the main blocks will be the development of rural areas (a variable block at the macroregion level), the improvement of technologies, especially in terms of the use of energy carriers, ensuring interregional integration in order to improve the conditions for the transportation of goods and the development of logistics. The implementation of these directions will lead to an improvement in the quality of population life, infrastructure development, and economic growth.

The northern regions of Russia have other features, their main task is to maintain the size and attract a new population, which we refer to the main block, in addition to this, the main blocks will include the development of technologies and the creation of infrastructure to meet the needs of the region.

We believe that the proposed author's model will ensure the proper level of sustainable development of the macroregion's territory and at the same time will be aimed at meeting national interests, which will positively affect the economic development of macroregions and the country, including the state of national security. The northern regions of Russia have other features, their main task is to maintain the number and attract new population, which we attribute to the main block, in addition, the main blocks will include the development of technologies and the creation of infrastructure to meet the needs of the region.

We believe that the offered author's model will ensure the proper level of sustainable development of the macroregion territory and at the same time will be aimed at satisfying national interests, which will positively affect the economic development of the macroregions and the country, including the state of national security.

\section{CONCLUSION}

Based on the conducted research, it is possible to formulate the main conclusions:

1. The concept of sustainable development is a relatively new, but relevant area of research, since it has a global character, and at the level of national economies affects the interests and priorities of the development of individual territories of the country.

2. The concept of "sustainable development" has distinctive features for different territorial levels (from local to global), which requires consideration when developing strategic documents, when drawing up these documents, it is necessary to rely on the main provisions of the national concept of sustainable development.

3. The offered author's model of territories sustainable development includes basic and variable blocks, where the basic block is a mandatory part for all territories, and variable blocks allow adapting the model for any level of the territory of the Russian Federation.

\section{AUTHORS' CONTRIBUTIONS}

Thus, the offered author's model of territories sustainable development has a certain scientific novelty, and its practical significance lies in the fact that this model can be recommended to managers, authorities when developing strategies for sustainable development of territories and other documents and programs.

\section{REFERENCES}

[1] A.N. Pasenov, Sustainable Development Concept: Historical and Legal Aspects. Scientific Bulletin. Philosophy Series. Sociology. Right 10(259) (2017) pp. 156-160.

[2] J. Report of the World Commission on Environment and Development "Our Common Future" 1987. http://www.un.org/ru/ga/documents/gakey.shtml.

[3] E. Sinitsyna, Concept of sustainable development. Electronic resource. http://cloudwatcher.ru/analytic s/2Mew/72/. 
[4] Decree of the President of the Russian Federation of February 4, 1994, No. 236 on the State Strategy of the Russian Federation for Environmental Protection and Sustainable Development. https://base.garant.ru/2108001/.

[5] Decree of the President of the Russian Federation No. 440 of April 1, 1996 "On the concept of the transition of the Russian Federation to sustainable development." M., 1996. http://government.ru/docs /all/17992/.

[6] Yu. A. Kuznetsova, Stages of formation and development of the concept of sustainable development. Young scientist 5 (2013) pp. 337-339.

[7] Law of the Republic of Moldova dated October 13, 2016 No. 239 "On Approval of the National Strategy for Regional Development for 2016-2020”. http://base.spinform.ru/show_doc.fwx?rgn=94201.

[8] Decision of the Government of the Republic of Moldova No. 409 of 04-06-2014 On the approval of the National Strategy for the Development of Agriculture and Rural Areas for 2014-2020. https://www.legis.md/cautare/getResults?doc_id=1 $10039 \&$ lang $=\mathrm{ru}$.

[9] Decision of the Government of the Republic of Moldova No. 377 of 10-06-2020 on the draft Law on the approval of the National Development Strategy "Moldova- 2030". https://www.legis.md/c autare/getResults?doc_id=121920\&lang=ru.

[10] N.C. Onat, M. Kucukvar, A. Halog, S. Cloutier, Systems Thinking for Life Cycle Sustainability Assessment: A Review of Recent Developments, Applications, and Future Perspectives. Sustainability 9(5) (2017) pp. 706-731.

[11] J. M. Diaz-Sarachaga, D. Jato-Espino, D. CastroFresno, Is the Sustainable Development Goals (SDG) index an adequate framework to measure the progress of the 2030 Agenda? Sustainable Development 26(6) pp. 663-671. DOI: https://doi.org/10.1002/sd.1735.

[12] M. J. Smith (2020). Sustainable Development Goals: Genuine global change requires genuine measures of efficacy. Journal of Maps 16(2). DOI: https://doi.org/10.1080/17445647.2020.1749386.

[13] D.H. Meadows, D.L. Meadows, J. Randers, W.W. Behrens, The Limits to Growth. Univers Books, 1972 p. 203.

[14] D. H. Meadows, J. Randers, D. L. Meadows, The Limits to Growth: the 30-Year Update. Universe Books, 2004, p. 338.
[15] K.Yu. Belousov, The current stage in the evolution of the concept of sustainable development and the formation of the corporate sustainability paradigm. Problems of the modern economy 1(45) (2013) pp. 47-50.

[16] M.S. Pashkevich, V.M. Shapoval, Preconditions for the formation, essence and evolution of the concept of sustainable development. Science and the world 2(4) (2014) pp. 40-45.

[17] G.P. Krasnoshchekov, G.S. Rosenberg, Chronology (calendar) of events related to the formation of ideas about "Sustainable Development". Samarskaya Luka: problems of regional and global ecology 17(2) (2008) pp. 221-288.

[18] Kh.N. Gizatullin, V.A. Troitsky, The concept of sustainable development: a new socio-economic paradigm. Social sciences and modernity 5 (1998) pp. 124-30.

[19] T.V. Alferova, E.A. Tretyakova, Conceptual modeling of the definition of the category "sustainable development". Journal of Economic Theory 4 (2012) pp. 46-52.

[20] A.V. Karpushkina, Problems of economic security: new global challenges and trends. SUSU Publishing Center, 2021, p. 652.

[21] S. V. Orekhova, Business model development of a traditional industrial enterprise. Journal of Advanced Research in Law and Economics 7(7) (2016) pp. 1798 - 1811. DOI: https://doi.org/10.14 505/jarle.v7.7(21).27.

[22] D.O. Skobelev, Industrial policy for improving resource efficiency and achieving sustainable development goals. Journal of New Economy 21(4) (2020) pp. 153 - 173. DOI: https://doi.org/10.2914 1/2658-5081-2020-21-4-8.

[23] Order of the Government of the Russian Federation of 04.02.2009 N 132-r "On the Concept of Sustainable Development of the Indigenous Peoples of the North, Siberia and the Far East of the Russian Federation". https://www.garant.ru/products/ipo/pri $\mathrm{me} / \mathrm{doc} / 94908 /$.

[24] Order of the Government of the Russian Federation of 25.08.2016 N 1792-r (revised from 23.11.2020) "On approval of the action plan for the implementation in 2016 - 2025 of the Concept of sustainable development of the indigenous peoples of the North, Siberia and the Far East of the Russian Federation". https://www.garant.ru/products/ipo/pri $\mathrm{me} / \mathrm{doc} / 71375714 /$.

[25] Order of the Government of the Russian Federation of 02.02.2015 N 151-r (as amended on 13.01.2017) 
"On approval of the Strategy for sustainable development of rural areas of the Russian Federation for the period up to 2030". https://www.garant.ru/products/ipo/prime/doc/7076 1426/.

[26] Order of the Government of the Russian Federation of January 30, 2018 N 118-r (as amended on April 29, 2021) "On the plan of measures for the implementation in 2018 - 2020 of the Strategy for the sustainable development of rural areas of the Russian Federation for the period up to 2030". https://www.garant.ru/products/ipo/prime/doc/4006 40029/.

[27] Decree of the President of the Russian Federation of 02.07.2021 N 400 "On the National Security Strategy of the Russian Federation". https://www.garant.ru/products/ipo/prime/doc/4013 $25792 /$.

[28] Order of the Government of the Russian Federation of 13.02.2019 N 207-r (as amended on 23.03.2021) "On approval of the Strategy for the spatial development of the Russian Federation for the period up to $2025 "$. https://sudact.ru/law/rasporiazh enie-pravitelstva-rf-ot-13022019-n-207-r/.

[29] E.G. Animitsa, N.M. Ratner, M.D. Sharygin, Ural region: socio-economic development (geographical aspect). Ural Branch of the USSR Academy of Sciences, 1992.

[30] E.G. Animitsa, A.V. Glumov, Sredinny region: theory, methodology, analysis. Ural Publishing House. State Economy University, 2007, p. 296. 